Resenha de livros

Esta seção destina-se à apresentação de resenhas de livros de interesse

para a bioética

\title{
A questão ética e a saúde humana
}

SEGRE, M. (Org.).

São Paulo: Editora Atheneu, 2006.

ISBN: 85-737-9792-4

O livro A questão ética e a saúde humana, organizado de forma competente pelo Professor Marco Segre, conta com nomes destacados da bioética brasileira, todos relacionados à área da saúde. Os vinte e um capítulos são divididos em Parte Geral e Parte Especial. Na parte geral são apresentados os aspectos conceituais e questões sociais e de ensino e pesquisa em bioética, temas que constituem os seis capítulos iniciais. Na parte especial são abordados vários temas relacionados aos avanços científicos e reflexões bioéticas sobre problemas atuais em áreas específicas da saúde.

Marco Segre abre o primeiro capítulo da coletânea com o artigo Conceitos de ética e bioética: bioética e suas tendências, no qual expõe as idéias desenvolvidas por ele e vários colaboradores desde 1995, que consubstanciam a Ética da Reflexão Autônoma. Para esse autor, que defende o pressuposto da eticidade das ações humanas, a ação ética deve ser pautada pela coerência atitudinal, que decorre da consciência individual e da reflexão autônoma peculiar aos seres humanos. Assim, a tomada de decisão frente aos dilemas morais vem da análise pessoal do indivíduo afetado, sendo o não cumprimento de tal condição a negação de sua autonomia

Franklin Leopoldo Silva assina o segundo capítulo Ética e saúde na pós- modernidade, mostrando que vivemos uma "era do abandono dos princípios gerais e fundamentos suficientes pela constatação que a tentativa de construí-los teria sido ilusória". Discutindo um aspecto marcante na construção dos valores na pós-modernidade, mostra que não se pode mais falar de moral, mas de moralidades, englobando assim o pluralismo de valores, sem pretensão de unificação. 


\section{Revista Brasileira de Bioética}

O capítulo terceiro, Os princípios da bioética, vem assinado por Fermin Roland Schramm e aponta os inegáveis méritos da bioética principialista na consolidação da bioética. Não obstante, o autor apresenta também a idéia de que ética não é prática, mas sim conhecimento com característica transcendente, que precisa ser utilizado a partir de métodos neutros e imparciais.

Em Ética aplicada, exclusão social e educação no contexto dos países do Hemisfério Sul, Volnei Garrafa discute a "absoluta falta de propostas políticas palpáveis que possam transformar os rumos do mundo para melhor". Defende a necessidade da mudança de parâmetros distributivos na área econômica, científica e tecnológica, apontando que estes devem estar orientados pelas idéias de compromisso e responsabilidade social. Fundamenta sua argumentação na educação, considerada por ele mecanismo concreto e factível na busca de mudanças.

No capítulo Ensino e bioética, José Eduardo de Siqueira aponta a insuficiência de uma base ética na formação médica frente aos grandes dilemas da atualidade. Mostra que a deontologia é insuficiente para orientar a ação ética, já que os problemas cotidianos apresentados ao médico são muito mais de natureza ética que técnica. O autor tece ainda reflexões sobre como se pode ensinar bioética, exemplificando seu ponto de vista com a experiência pedagógica aplicada na Universidade Estadual de Londrina, Paraná e em outras escolas médicas do país e do exterior.

Encerrando a primeira parte do livro, o capítulo Pesquisa em ética, de Reinaldo Ayer de Oliveira e Marco Segre, afirma que o "progresso científico não é sinônimo de progresso da humanidade". A construção do argumento que sustenta essa afirmativa está embasada na revisão na evolução histórica da ética na pesquisa envolvendo seres humanos. Os autores apontam, ainda, que a pesquisa bioética é qualitativa, não devendo ser dogmática nem persuasiva, mas criativa. Colocam a reflexão sobre a dificuldade da pesquisa nesse campo, basicamente reflexivo, no qual os aspectos afetivos são muito poderosos.

A parte especial aborda temas específicos, na qual os autores demonstram raciocínios de grande profundidade que merecem ser lidos com vagar e reflexão. O organizador colocou os temas em uma seqüência bastante interessante, que remete à compreensão do próprio fluxo da existência. Tal ordenamento parte da autonomia na relação entre o 
profissional de saúde e o usuário, com o tema: A relação entre o profissional de saúde e o usuário de suas atenções, vista a partir do princípio da autonomia - escrito por Flávio Carvalho Ferraz. O trabalho fala da mudança do paternalismo para a autonomia na história, assim como da formação do sujeito moral.

Na seqüência vem o tema Considerações éticas sobre biologia molecular, escrito por Gilka J. Figaro Gattás e Marco Segre, com a discussão sobre a facilidade no diagnosticar e a dificuldade do tratar, incluindo também os aspectos éticos que envolvem a informação e a manipulação genética.

Em Considerações éticas sobre o início da vida: Aborto, reprodução assistida e clonagem de seres humanos, Segre reflete sobre o início da vida, discorrendo sobre a indefinição do que sejam vida e morte, parâmetros fundamentais da discussão bioética. Consoante à perspectiva teórica que desenvolve, o autor mostra que as definições são feitas "de fora" e não "de dentro". O capítulo lista ainda as leis e normas brasileiras sobre o assunto.

Continuando o fio condutor do livro, iniciada a vida, Thomaz Rafael Gollop fala sobre os Aspectos éticos em medicina fetal. Discorre sobre o feto poder ser tratado como paciente, apontando que esse avanço se relaciona com a discussão bioética e com o reconhecimento da importância de considerar as questões que envolvem o trinômio feto-mãe-pai e seus possíveis conflitos.

Nascido o ser humano, a bioética terá que refletir sobre os Aspectos éticos do relacionamento entre o profissional de saúde e o paciente pediátrico. Este tema é abordado por Gabriel Oselka, Clóvis Francisco Constantino e Mário Roberto Hirscheimer, que mostram a dificuldade de estabelecer os limites da autonomia da criança e do adolescente.

Na seqüência montada pelo organizador, a partir do Capítulo 12, os assuntos são grandes temas da atualidade: doenças, quimiodependência, envelhecimento populacional, finitude humana, pesquisas envolvendo seres humanos, bioética em segmentos especializados da medicina, terminando com um assunto importante e pouco refletido, que é a mídia nas questões de saúde.

Em Aids e ética, Caio Rosenthal e Mário Scheffer mostram como essa doença alterou aspectos culturais e sociais, subvertendo crenças religiosas e colocando em xeque verdades científicas. 


\section{Revista Brasileira de Bioética}

Telesforo Bacchella e Reinaldo Ayer de Oliveira refletem no capítulo seguinte sobre as necessidades de órgãos e tecidos para transplantes e de uma classificação dos potenciais doadores. Além dessa discussão, Bioética dos transplantes transcreve a legislação brasileira pertinente ao assunto.

O Capítulo 14 é escrito por Cláudio Cohen e José Álvaro Marques Marcolino e trata dos Aspectos bioéticos em psiquiatria. A reflexão começa citando Frankena e suas idéias sobre moralidade, passando pelos temas da beneficência e paternalismo na psiquiatria, terminando pelos aspectos legais de admissões hospitalares involuntárias de pacientes para tratamento.

Em Ética e terceira idade, Mário Mosca Filho reflete sobre o aumento do número crescente de idosos verificado tanto no Brasil como nos demais países em desenvolvimento; discorre ainda sobre o problema da alocação de recursos para atendê-los. Expõe o processo de envelhecer e suas conotações pessoais e sociais, propondo um modelo de institucionalização do atendimento ao idoso.

Maria Júlia Kovács faz um estudo sobre os Aspectos éticos referentes à abreviação da vida, eutanásia, ortotanásia e suicídio assistido. A tônica principal é que consiste em erro médico enfocar o combate à morte. A finalidade da medicina é combater doenças, não o doente. É colocada a seguinte questão: é possível escolher a forma de morrer?

No capítulo seguinte, Elma Zoboli estuda O cuidado: uma voz diferente na ética da saúde, no qual defende a idéia de que o cuidado traz à baila o conceito de eqüidade. É questionada a idéia de que o tratamento que não apresenta resultado desemboca no cuidado. A autora defende que, em qualquer doença, desde o princípio, deveria ser buscado o cuidado, o qual deve ser entendido como inerente ao tratamento.

No tema Bioética e cirurgia plástica, Luis Bernardo Fróes e Marco Segre refletem sobre especificidades da cirurgia plástica. Nessa especialidade é quase impossível a criação de modelos experimentais de pesquisa, existindo uma interface muito tênue no que seja plástica estética e reparadora. A reflexão dos autores abarca a cirurgia plástica estética, com suas demandas individuais, sociais e institucionais.

Marco Segre e Sérgio Dário Seibel voltam a discutir a autonomia em Aspectos éticos das atenções de saúde com relação ao dependente 
de drogas e defendem a idéia de que droga não é problema de polícia, mas questão de saúde. Mostram o processo histórico da luta contra as drogas nos Estados Unidos da América do Norte e o insucesso das Cortes de Drogas. Refletem também sobre a importação acrítica do modelo de repressão e controle estadunidense para o Brasil.

No penúltimo capítulo, Bioética - Pesquisa envolvendo seres humanos, William Saad Hossne expõe que, mesmo atendendo às normas, a experiência em um determinado momento é aplicada ao ser humano e não deixa de ser uma experiência em seres humanos. $\mathrm{O}$ autor cita e explica normas e leis existentes em outros países e as regulamentações brasileiras, que considera boas por não estarem subordinadas aos órgãos governamentais ou de classes.

O livro organizado por Marco Segre termina com as reflexões sobre os Aspectos éticos da mídia relacionada à questão de saúde, feitas por Cláudio Júlio Tognolli. Sua colocação central é sobre o biologismo como uma demanda de trabalho cada vez mais seletiva. Analisa publicações dos últimos dez anos e constata que 98\% dos artigos encaram os genes como a resposta final, esquecendo que estes se modificam em decorrência de condições ambientais, sociais e das relações de trabalho: "O gene não pode ser substituído como uma peça de computador como faz crer nosso espírito de época".

A leitura do livro organizado por Segre é estimulante, instigadora e muito agradável. Embora os assuntos sejam variados, existe um fio condutor lógico. Pela atualidade e importância dos assuntos, merece ser lido e mantido à mão para releitura.

\section{Etelvino de Souza Trindade}

Unidade de Ginecologia Oncológica do Hospital de Base do Distrito Federal, Brasília, Distrito Federal, Brasil.

estrinda@brturbo.com.br 